\title{
液態泫炭の泫炭防止に關する研究 *
}

$\begin{array}{llll}\text { 小 } & \text { 喜 代 } \\ \text { 山* } & \text { 本 壮 兵 衛 } * * *\end{array}$

Study on the Protection Method in the Carbo-Nitriding Process of Steel.

\section{Kiyokazu Ogawa and Sobe Yamamoto}

In this paper, we studied on the protection methods in the Carbo-Nitriding process of steel, and found that as follows.

1. Using the painting mixture of $\mathrm{Al}_{2} \mathrm{O}_{3}$ (or $\mathrm{SiO}_{2}$ ) and $\mathrm{Na}_{2} \mathrm{SiO}_{3}$, plating of $\mathrm{Zn}, \mathrm{Cu}, \mathrm{Ni}$, and $\mathrm{Cr}$, and $\mathrm{Al}$ metallizing process, it was found that uing the Al metallizing process was the most effective and reasonable.

2. The utility thickness of the $\mathrm{Al}$ metallizing layer was about $1 \mathrm{~mm}$., and the protective effect was found when its thickness was more than $1 \mathrm{~mm}$.

3. In the investigatiou on the durability of Carburizing salts in which these protection method were used, it was found that the decay of the salt was not recognized using the Al metallizin $-\mathrm{g}$ method.

\section{1. 緒 言}

鉄鋼の表面硬化の一方法として青化塩の高溫化学反応 を応用した液態炭法 (別に滲炭絰化法とも呼ばれる) は工業的にも広く用いられ，一般知られているるので ある。この方㚘は $\mathrm{NaCN}$ を基剤とする熔融塩を用い, 高 溫で䒚室化作用を迅速几行い，鉄鋼表面を硬化せしめ るのがその目的であるが，一方この崖作用を部分的に 阻止する事る工業的には種及要求される事がある。然る 飞固態䒚法の場合では銅鎦金を施す事により，比較的 簡単にその目的を達しているが(1)夜態湌炭洗に於ては之 が頗る困難であり，從つて液態沴炭法についての一つの 難点として, 徒来から問題となつていたるのである。

本実験ではこの点について数種の防止処理に関する効 果並びに之が塩浴に及济す影響に就ての研究を行つた。

\section{2. 寞 驗 方 法}

鋼材試料は0.1 0.2\% $\mathrm{C}$ の肌焼鋼を用い，その形状は $10 \times 10 \times 20 \mathrm{~mm}$ 又は $2 \times 15 \times 50 \mathrm{~mm}$ の板として用いた。

加熱の方泆沈内径 $80 \mathrm{~mm}$, 高さ $200 \mathrm{~mm}$ の縦型管状爐 にガスバーナーを切線状に插入したガス爐を用い，その 中に中性 (Alandam 質) の圤㺃を插し, 之に滲炭性混 合塩を熔融した。

* 昭和28年10月 大阪大会に発表

** 都立工業楽励館 工博

***同止
実験に用いた滲炭性塩浴は純度 $90 \%$ の NaCN30\%に, $\mathrm{BaCl}_{2} 70 \%$ を添加した共晶組成のもので，この混合熔融 塩は, 炭層及びその促進性の大きいことが認められて いる組成であり (2)，工業的にも広く用いられているすの である。処理溫度は実用的な溫度を考慮して $850^{\circ} \mathrm{C}$ 一定 とし，鋼材試料はこの溫度に於て，1時間宛浸清した後 何れも油焼入した。この液態炭处理は滲炭と同時に窒 化も行われるが，処理溫度が850 $\mathrm{C}$ に於ては沴炭の影響 が主体となる(2)。

以上の如き條件に於て，㳂炭処理を行了鋼材に，夫火 次の樣な防止処理を施し，その効果の検討を行つた。

1， $\mathrm{Al}_{2} \mathrm{O}_{3}$ 及び $\mathrm{SiO}_{2}$ と $\mathrm{Na}_{2} \mathrm{SiO}_{3}$ を用いたるの

2. $\mathrm{Zn}, \mathrm{Cu}, \mathrm{Ni}, \mathrm{Cr}$, 等の電気鍍金を用いたもの。

3. $\mathrm{Al}$ メタリコン法を用いたるの。

何実験に採用した防止剤が，鍍金の場合を除くと，他 は何れも主として $\mathrm{A} 1$ 系のものを用いたが，炭性塩浴 の基㓮となるCNと $\mathrm{Al}$ は相反した作用を有し，A1は鉄炭 化物を分解する性質を有するため，表面炭素濃度を低下 させるか(3)，又は炭窒化作用を不能にする。な技，塩 浴中に Al を熔融すると液の少化が促進されることが認 められて招り(4), 徒つてCN の鋼材に更ぼす反応を阻止 する意味で $\mathrm{Al}$ 系のものについて実験を行つた。

然しながら，Al が前述の如く塩浴中に熔解してCNを 消耗せしめるならば，例之防止効果が良好であつてる， 塩浴自体の少化子促進される事になる。即ち防止皮膜が $\mathrm{Al}$ あるか，又は $\mathrm{Al}_{2} \mathrm{O}_{3}$ の状態にあるかによつて液の少 
化が相異する。従つて此処では鋼材の反応防止を検討す ると同時に，塩浴に及ぼす影響についてす常に吟味を行 つた。

\section{3. $\mathrm{Al}_{2} \mathrm{O}_{3}$, 及び $\mathrm{SiO}_{2}$ と $\mathrm{Na}_{2} \mathrm{SiO}_{3}$ の混合物に よる防止効果}

比㣀的粒度のそ万つた \#200〜 \#300の $\mathrm{Al}_{2} \mathrm{O}_{3} \quad 5 \sim 40 \%$ に $\mathrm{Na}_{2} \mathrm{SiO}_{3}$ を混合して粘土状となし，これを鋼材表面に

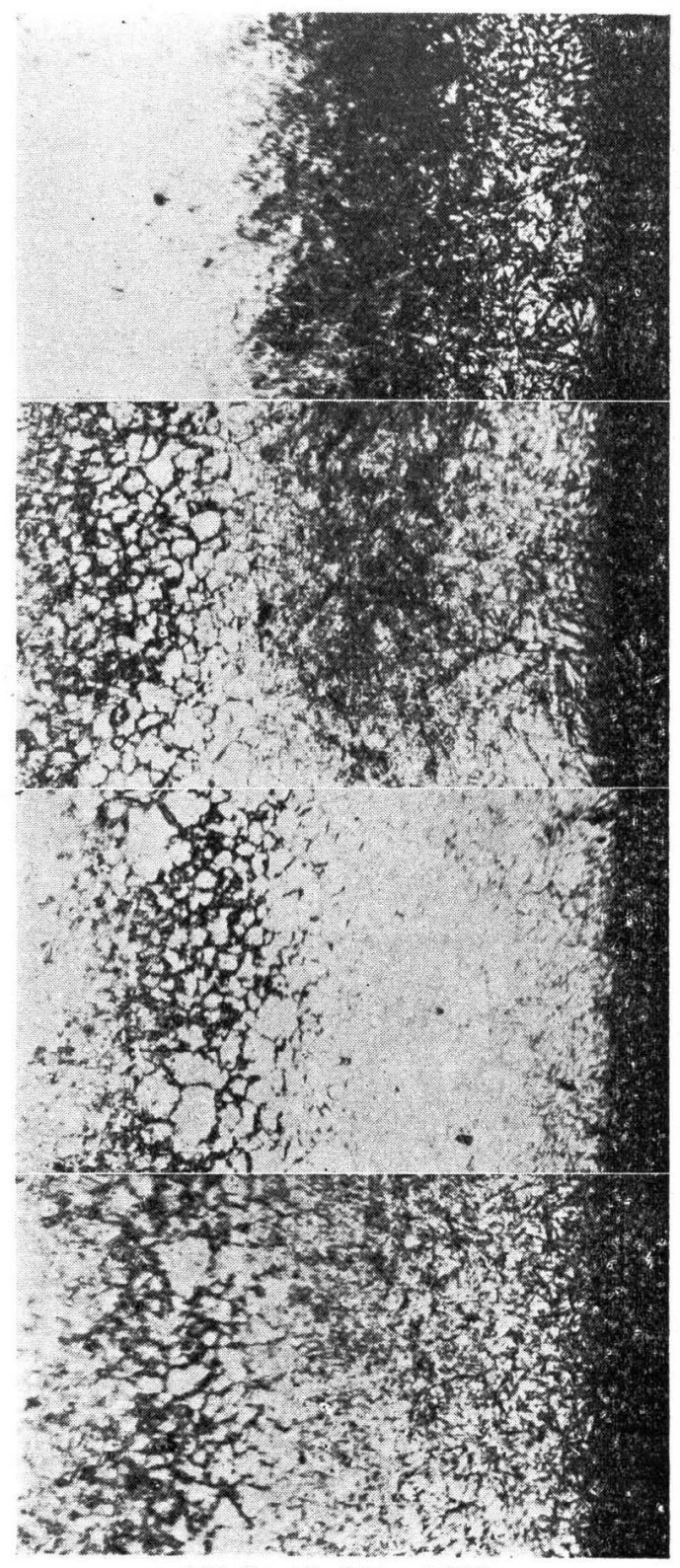

$\left(\mathrm{Al}_{2} \mathrm{O}_{3}+\mathrm{Na}_{2} \mathrm{SiO}_{3}\right.$ +黒糖 $)$

脚註 写真1 4k於て滲炭層は何孔もMartensite 組織 を示しているが濃度の相異が見られるのは冷却速 度の影響である。 1〜2mmの厚さに塗付して, 乾燥した後に塩浴中に浸漬 処理した。

その結果によると, $850^{\circ} \mathrm{C}$ に於ては $\mathrm{Na}_{2} \mathrm{SiO}_{3}$ が熔融, 或は燃焼して, 試料面党の密着性がなく, 主㓮となる $\mathrm{Al}_{2} \mathrm{O}_{3}$ は塩浴中に浮遊して防止効果は全くなかつた。

寫真 1 4は $\mathrm{Al}_{2} \mathrm{O}_{3} \quad 10,15,30$ 及び $40 \%$ を $\mathrm{Na}_{2} \mathrm{SiO}_{3}$ と混 じた場合の組織を示すものであるが，防止性がなく通常 の宸組織層を示している。
寫㝵 1

$\mathrm{Al}_{2} \mathrm{O}_{3} \quad 10 \%$

$\times 80$

寫道 2

$\mathrm{Al}_{2} \mathrm{O}_{3} \quad 15 \%$

$\times 80$

富 3

$\mathrm{Al}_{2} \mathrm{O}_{3} \quad 30 \%$

$\times 80$

寫迻 4

$\mathrm{Al}_{2} \mathrm{O}_{3} \quad 40 \%$
次いでこの防止剤を試料面え一層 强く固着せしめる目的で，之に30\% の黑糖を加えその炭化による固着を 考えたが, この場合にも $\mathrm{Na}_{2} \mathrm{SiO}_{3}$, 黒糖共に燃狫して, 表面より彔離し, 黒糖添加の勃果はなく, 防止の効果 は認められなかつた。

又 $\mathrm{Al}_{2} \mathrm{O}_{3}$ と $\mathrm{SiO}_{2}$ と招きか点て同樣 の実験を行つたが，これも防止㓮の 試料面えつ密着性が得られないとい ら事からその結果は同樣で女つた。

\section{4. $\mathrm{Zu}, \mathrm{Cu}, \mathrm{Ni}, \mathrm{Cr}$ 等の} 電氣鍍金による防止効果

前節の結果から嘧着性の悪い方沃 には効果の認められない事が明らか になつたので, 次に電気埌金を行つ て比較した。鍍金方洗は， Cr の,直 接銥金が多孔性であつて問題もある 為, $\mathrm{Zn}-\mathrm{Cr}$ (此の場合 $\mathrm{Zn}$ 上への $\mathrm{Cr}$ 䤲 金は一般に析出し難いのであるが， 此れは特殊の表面処理によつて良好 な析出を得た)についてCrを $45^{\circ} \mathrm{C}$, $15 \mathrm{~A} / \mathrm{dm}^{2}$ の下K夫ぬ5, 10, 15仮び 20 分行つたもの, 不び一般装飾鍍金で 行われている $\mathrm{Cu}-\mathrm{Ni}-\mathrm{Cr}$ を, 厚さ $7.7 \mu$, 及びNi-Cu-Ni-Cr のすのを $12.6 \mu$ 及び $19.2 \mu$ の厚さに電着して 行つた。

これによると，Zn を下地鍍金し たものでは塩浴処理溫度が $850^{\circ} \mathrm{C}$ で あるため, 浸清中に下地の $Z \mathrm{n}$ が熔 融し, 更にCN と区応する結果, $\mathrm{Cr}$ の剝離を生じ防止効果が認められな からた。

$\mathrm{Cu}-\mathrm{Ni}-\mathrm{Cr}$ $7.7 \mu$ の厚さのひの, 及び Ni-Cu-Ni-Cr の12.6 $\mu, 19.2 \mu$ の厚さのるのの 3 種 についた行つた結果は富面5７亿示す樣に， Cu-Ni-Cr の $9.7 \mu$ のるのは炭層の厚さを均一に減少せしめたが 


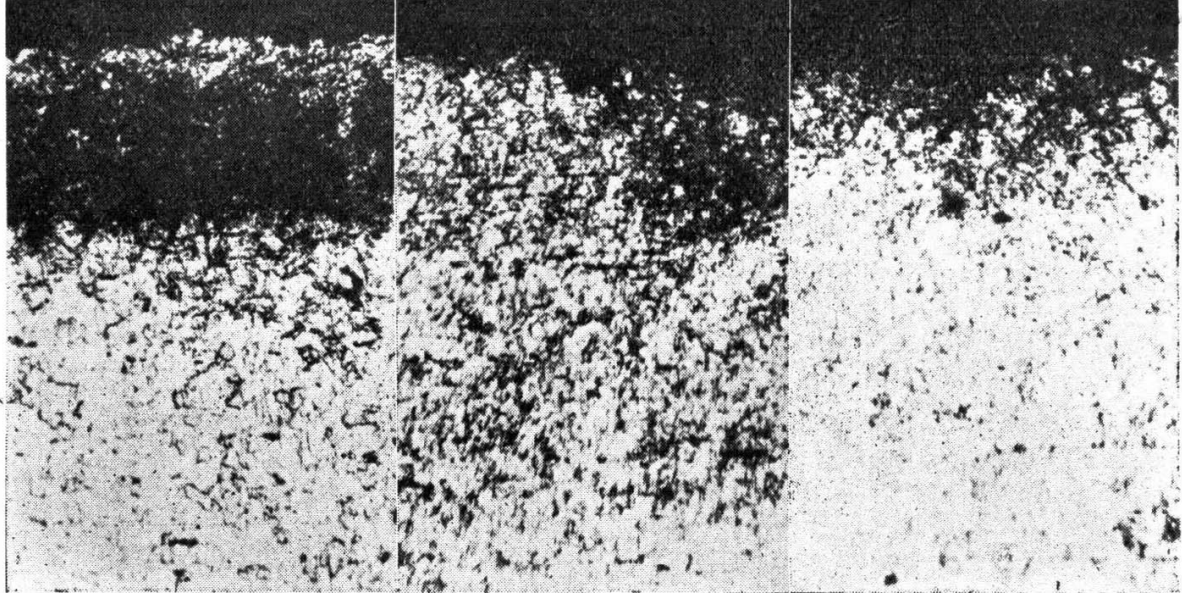

寞 $5 \times 80$

$\mathrm{Cu}-\mathrm{Ni}-\mathrm{Cr}, 8 \mu$
荀 頁 $6 \times 80$

$\mathrm{Ni}-\mathrm{Cu}-\mathrm{Ni}-\mathrm{Cr}, 12 \mu$
耍 $7 \times 80$

$\mathrm{Ni}-\mathrm{Cu}-\mathrm{Ni}-\mathrm{Cr}, 19 \mu$

$$
\text { (電気 鎪 金) }
$$

やはり表面は渗炭され，Ni-Cu-Ni-Cr の $12.6 \mu の$ のの る。

では部分的に渗炭凰が表れる程度となつた。更に $19.2 \mu$

のものでは殆んど防止されている事が確認された。この 事実よりして，この種の電気䥓金法は，その電着状態， 鍍金せる金属の種類等によつて影響はされるが，結果的 には全体として鉏金層が $10 \mu$ 以上 $20 \mu$ 程度の厚さを有する なら，防止效果がある事が認められた。

但し斯樣に，単独又は多層领金を鋼材に施寸事は，実 用上も，経済的にも困難が伴い，而もその防止部分が局 部的に要求される場合には，これは非常に困難であるか 或は不可能であるため，実用性に乏しいるのと考兄られ

\section{Al メタリコンを局いたものの防止効果}

第. 3 節の実験の樣に $\mathrm{Al}_{2} \mathrm{O}_{3}$ を用い, 且鋼材表面に $\mathrm{Al}_{2}$ $\mathrm{O}_{3}$ が緊密に附着する方洼として更に考察した結果， $\mathrm{Al}$ のメタリコン(熔射法)を用いてみた。即ち熔射された $\mathrm{Al}$ は熔融のために受ける熱と, 熔融状態で空気中を通 過するため，その大部分が $\mathrm{Al}_{2} \mathrm{O}_{3}$ となる事が考六られ， 徒つて鋼材表面に最方合理的に $\mathrm{Al}_{2} \mathrm{O}_{3}$ を密着させ得る方 浩でもると推考した。

試料表面に $\mathrm{Al}$ メタリコンを夫タ約 $0.2,0.4,0.8,1.0$,

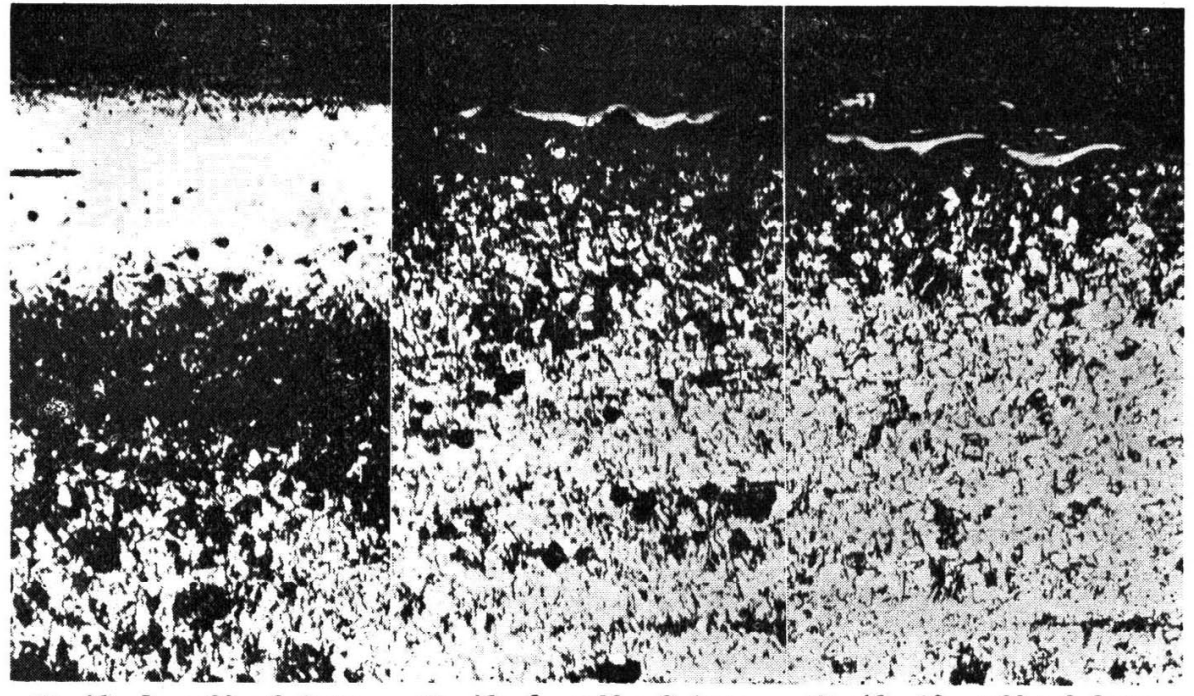

寫真 $8 \times 80 ; 0.2 \mathrm{~mm}$

寫

罟 眞 $10 \times 80 ； 0.8 \mathrm{~mm}$

(A1 メタリコン) 


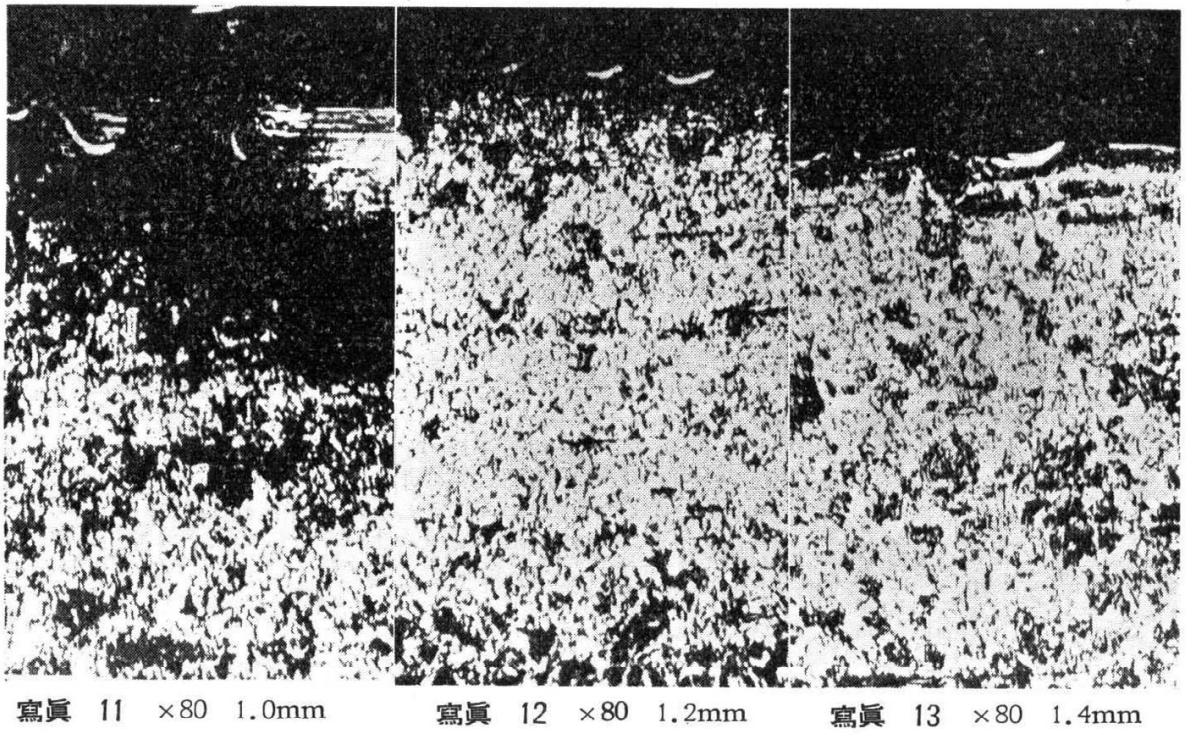

(Al メタリコン)

1.2,1.4mm の厚さに施した後, 同樣に汪炭性塩浴中に

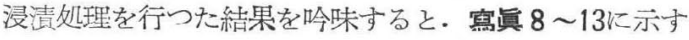
样に $0.2 \mathrm{~mm}$ ののでは滲炭が行われているが，0.4mm 程度から前項のCu-Ni-Crの7.7 $\mu$ の厚さのものと同程度 の部分的の防止効果を示し，0.8〜1.0mmで充分な防止 効果のある事を認㧹て，初期の目的孝達成する事が出 来た。更にこの方泩はメタリコンの愹射條件，即ち熔着 層の性質を改善する重により，上り薄い層であつて子防 止效果を認め得るものであららと考えられる。

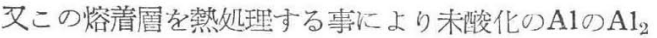

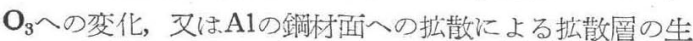
成を行い，その防止效果との関連を調べるために $900^{\circ} \mathrm{C}$ 及び $950^{\circ} \mathrm{C}$ に夫々一侍閒焼鈍老行い防止效果老检剑した がその拡散層は短時間处理のためか極めて微量で岁つて 防止効果は前訅のものと变らなからた。しか子妇液態㑢炭

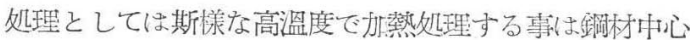
部の粒成長を促し，特䛈の場合以外は轮ましくないと考 完られる。

\section{6. 各種防止處理が鹽浴の耐久力に 及ぼす影響}

以上行つた备及の防止处理の実用性を塩浴面加ら田

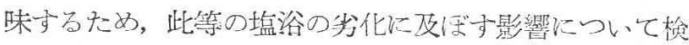
討を行つた。即ち如何に防止效果を認め得て子, 之に上 つて塩浴の少化が伴う時は実用性にそしい。また $\mathrm{Al}_{2} \mathrm{O}_{3}$ は $\mathrm{CN}$ と直接反応しないが， $\mathrm{Al}_{2} \mathrm{O}_{3}+\mathrm{Na}_{2} \mathrm{O}=2 \mathrm{NaAlO}_{2}$ の

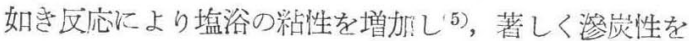
㳚少せしめる。特に酸化されないA1が存在し之が深炭性 篮浴飞熔融するときは，その塩浴は顥著に少化する事が
考学られる。徒つて夫々の処理に上る塩浴組成の変化, 特に $\mathrm{NaCN}$ の濃度の蔵少について実験を行つた。

実験は先ずブランクテストとして該組成の塩浴のみを $850^{\circ} \mathrm{C}$ に10时間連続熔融して 1 時閒每に塩浴試料を採取 し，CN 量について分析を行い，その結果を第1 圖に示 した。

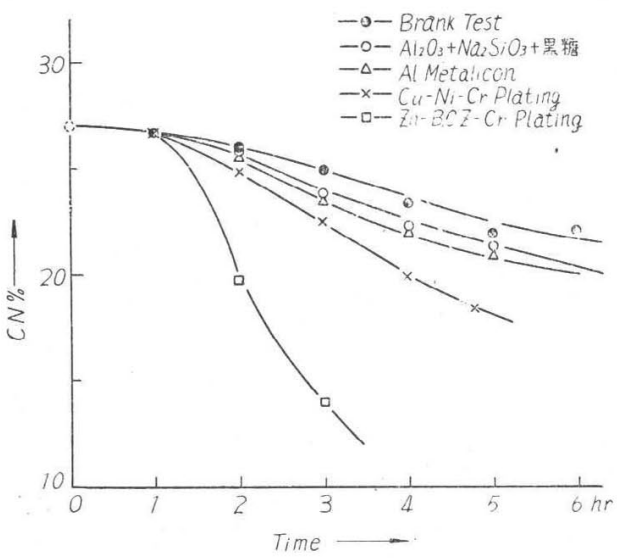

第1 圖 各種防止処理が塩浴の少化に及文ず影響

次に各及の防止处理を施した鋼材を塩浴中に浸清し， 滲炭防止処理を連続的に行うと共に塩浴試料を我採取し て，之考分析し，それ等の繥果第 1 圖に附記して，前 記ブランクテストと比皎した。

之に上ると同図に明らかな梯に, $\mathrm{Al}_{2} \mathrm{O}_{3}$ 塗付洙攻び， A1 メタリコン法を用いた場合は塩浴少化の傾问は㱠ん ぞ認められず，鍍金したものに於ては何れも少化の傾问 を認めた。特にZn-Cr の鈸金を施したものは，Zn が愹 融して鋼材と其に $\mathrm{CN}$ と民応する結果，著しい劣化が観 
察されな打 $\mathrm{Cr}$ 子一部反応するるのの樣で熔骶塩が薄緑 乃至は薄青色に滞色しているのを認めた。

佮本実験で用いたNaCN の純度は先述の如く90.36\% であり，30\%添加すると，熔融直後は27\%程度となる。

\section{7. 結言}

本報告は $\mathrm{NaCN}$ を基蝺とする鋼材の液態炭処理に於 て，その防止泆の実験を行い，次の事柄を認めた。

1. $\mathrm{Al}_{2} \mathrm{O}_{3}$ 及び $\mathrm{SiO}_{2}$ と $\mathrm{NaSiO}_{3}$ の混合物, $\mathrm{Zn} . \mathrm{Cu}, \mathrm{Ni}$, $\mathrm{Cr}$ 等の電気錙金, $\mathrm{A} 1$ ×タリコン等の沴炭防止处理 に於いて, $\mathrm{Al}$ メタリコン法が最も合理的で効果のあ る事を知つた。

2. $\mathrm{A} 1$ ×タリコンの実用的な厚さは約 $1 \mathrm{~mm}$ で，之よ
り以上の場合に効果が認められた。

3. 各種処理に対寸る塩浴の耐久力についての实験を 行つた結果, $\mathrm{A} 1$ メタリコン法によるる塩浴の少化は 殆んぞ認められない事を知つた。 （昭和28年 7 月 21 日受理）

\section{交献}

（1）石沢 命知，鋼の宸々堂化 (1934) 45

（2）小川喜代一，日本金属学会誌 B 14 (1950) 12

（3）河上 益夫, 東京工大報告 昭和13 No. 7

（4）小川喜代一，日本金属学会 第IV分科会誌

(5) J.W.Meller, A Comprehensive Treatise on Inorganic and Theoretical Chemistry 5 p. 288

\title{
金屬表面上に於ける有機物質の接觸角の研究
}

\author{
淺 原 照 三* 後 藤 健 - * *
}

\section{Studies on the Contact Angles of Organic Substances on the Metal Surfaces}

\author{
Teruzo ASAHARA and Ken'ichi GOTO
}

\section{1. 緒論}

固相液相気相系の接触角の研究に就ては, 古来幾多の 研究が行われているが，接触有が表面張力や界面張力と 同樣に一つの物性を示す量として，種くの応用が期待さ

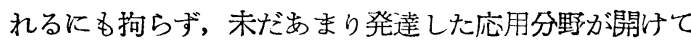
いない樣に思われる。これはその測定方法に優れた決定 的なすがなく，接術的に为装置の点からも取扱いにく い量であり，そればかりでなく，一般に金属のような固 体物質の表面は，非常に複雑な相貌を呈するので，測定 值の再現性に影響する要因が多く，その為に研究が拈く れているのではなかららか? こうした困難や欠点を解 決するには，測定方法の誤差と，環境條件の效果とを統 計的に対決せしめることにより，環境條件や実験方法の 制御を行い得て，はじめて測定の標準方式を確立出来， 測定值の再現性を高めらるものであろら。筆者等は, 東 大永井雄三郎教授を中心とする"金属表面上の有機物質 の挙動いと云う綜合研究の一環として接触危の研究を担 当して抢り，これは各種金属表面上で，種々の有機物質

* 東京大学 生産技術研究所
が如何なる接触危を呈し，それが表面の状態とどの樣な 関係にあるかを考察し，同時に直接間接に接触角と相関 関係のある諸量を見出すことによつて，例えば，金属表 面処理法や，防蝕油の基礎研究等に寄与せしめることを 究極の目的としている。この報文にはその一部として, 筆者等の考案した測定方式により，アルミニウム，銅， 亞鉊, 真鍮, 鉄等の表面に対する流動パラフインの接触 角を測定した結果を紹介し，今後研究を進める上への糧 としたい。

\section{2. 接觸角及びその測定}

液滴が完全に平滑で水平な固体の表面倿触するとき は，それは無限に拡がるか或はある一定限度の広さまで ひろがつて液体面と固体面の閒に一定の售度を保つて, 本衡心到達するかのいずれかであろ5。多くの場合実際 には, 後者が実現されるのであるが, この際, 液体と固 体の接触点に扔いて第1國の上ろに液面に切線を引き， これと固体面とのなす角を名付けて接触角と云う。所で 表洎張力の大小によるこの本衡状態は第 2 圆に示すよう な幾何学的図形であらわされる。図に示すよらに液商の 接触円半径を $\boldsymbol{r}$, 高さをhとすると，接触看 $\boldsymbol{\theta}$ は 